Sousa, M.G.'; Higa, A. '; Gerardi, D.G.'; Ferreira, L.S.'; Teshima, E.'; Carareto, R.' ; Tinucci-Costa M. '; Carvalho, T.'

\section{8 - Síndrome do cão tremedor em um Pinscher}

1- Departamento de Clínica e Cirurgia Veterinária da Faculdade de Ciências Agrárias e Veterinárias da Universidade Estadual Paulista (UNESP), Campus de Jaboticabal, Jaboticabal-SP

A sindrome do cão tremedor é uma desordem neurológica, mais freqüentemente observada em cães jovens, associada com inflamação leve do sistema nervoso central, onde o animal apresenta tremores difusos pelo corpo, sendo estes sinais inicialmente confundidos com apreensão ou hipotermia. Para o estebelecimento do diagnóstico, é importante descartas outras causas de fraqueza, apreensão, hipotermia e convulsão. Este trabalho tem por objetivo descrever um caso de síndrome do cào tremedor, em um Pinscher, macho, de 2 anos de idade, que foi trazido ao atendimento devido à queixa de tremores generalizados pelo corpo, os quais foram percebidos pelo proprietários desde que o animais tinha 6 meses de idade. Ao exame fisico, o animal apresentava mucosas normocoradas e nenhuma alteraçào à auscutação cardiopulmonar $\mathrm{e}$ à palpação abdominal. Como parte do exame físico, procurouse deixar o animal por alguns minutos sob o sol, com o intuito de descartar a possibilidade de tremor devido à sensibilidade térmica. Foram solicitados exames laboratoriais, incluindo perfil hematológico e bioquímico (ALT, FA, Uréia, Creatinina, Colesterol, Triglicérides, Glicemia, Albumina, Proteína Total, Cálcio, Fósforo, Sódio e Potássio). Adicionalmente, também foi realizado perfil tireoidiano, sendo que todos os exames apresentaram resultados dentro da faixa de normalidade para a espécie. Tendo sido feito o diagnóstico diferencial para cinomose, hipotireoidismo, distúrbios eletrolíticos dentre outras, estabeleceu-se o diagnóstico de síndrome do cào tremedor. Subseqüentemente, o animal passou a receber predinisona, na dose de $2 \mathrm{mg} / \mathrm{kg}, 2$ vezes ao dia, além de sulfametoxazol associado ao trimetropim, na dose de $15 \mathrm{mg} / \mathrm{kg}$, também 2 vezes ao dia. $\mathrm{O}$ animal foi reavaliado após 1 semana, tendo apresentado sensivel minimização dos tremores. $\mathrm{O}$ tratamento foi continuado por 1 semana, com nova reavaliação, sendo então verificado que os tremores estavam praticamente ausentes. Procedeu-se entào ao início da redução da corticoterapia de forma progressiva, de modo que, ao término do $30^{\circ}$. dia de tratamento, o animal passou a não receber mais qualquer fármaco. $\mathrm{O}$ animal nào apresentou tremores por periodo de 26 dias após a retirada do corticóide, tendo em seguida, apresentado recidiva do quadro. A corticoterapia foi reintroduzida, com melhora do quadro clínico de forma similar ao anterior: Procedeu-se nova retirada do medicamento de forma similar e, após 18 dias, o animal voltou a apresentar os tremores. Desse modo, optou-se por reintroduzir o corticóide e, após 1 semana, iniciou-se o decréscimo da dose até atingir $0,25 \mathrm{mg} / \mathrm{kg} 1 \mathrm{vez}$ ao dia, a cada 3 dias, a qual ainda vem sendo fornecida ao animal, que nào voltou a apresentar sinais clíncos da sindrome. Espera-se com este relato, auxiliar outros clínicos na elucidação de casos semelhantes, enfatizando-se a necessidade de diagnóstico diferencial de outras enfermidades e/ou circunstâncias que possam levar ao aparecimento dos tremores. Adicionalmente, reforça-se a importância de um cuidadoso acompanhamento do paciente, face aos possíveis efeitos adversos da terapia prolongada com coricosteróide. 